\title{
Cells involved in extracellular matrix remodeling after acute myocardial infarction
}

\author{
Células envolvidas no remodelamento da matriz extracelular após infarto agudo do miocárdio \\ Larissa Ferraz Garcia ${ }^{1}$, Fábio D’Aguiar Mataveli², Ana Maria Amaral Antônio Mader'1, \\ Thérèse Rachell Theodoro ${ }^{1}$, Giselle Zenker Justo ${ }^{2}$, Maria Aparecida da Silva Pinhal ${ }^{2}$
}

\begin{abstract}
Objective: Evaluate the effects of VEGF ${ }_{165}$ gene transfer in the process of remodeling of the extracellular matrix after an acute myocardial infarct. Methods: Wistar rats were submitted to myocardial infarction, after the ligation of the left descending artery, and the left ventricle ejection fraction was used to classify the infarcts into large and small. The animals were divided into groups of ten, according to the size of infarcted area (large or small), and received or not $\mathrm{VEGF}_{165}$ treatment. Evaluation of different markers was performed using immunohistochemistry and digital quantification. The primary antibodies used in the analysis were anti-fibronectin, anti-vimentin, anti-CD44, anti-E-cadherin, anti-CD24, anti-alpha-1-actin, and antiPCNA. The results were expressed as mean and standard error, and analyzed by ANOVA, considering statistically significant if $p \leq 0.05$. Results: There was a significant increase in the expression of undifferentiated cell markers, such as fibronectin (protein present in the extracellular matrix) and CD44 (glycoprotein present in the endothelial cells). However, there was decreased expression of vimentin and PCNA, indicating a possible decrease in the process of cell proliferation after treatment with VEGF ${ }_{165}$. Markers of differentiated cells, E-cadherin (adhesion protein between myocardial cells), CD24 (protein present in the blood vessels), and alpha-1-actin (specific myocyte marker), showed higher expression in the groups submitted to gene therapy, compared to non-treated group. The value obtained by the relation between alpha-1-actin and vimentin was approximately three times higher in the groups treated with $\mathrm{VEGF}_{165^{\prime}}$ suggesting greater tissue differentiation. Conclusion: The results demonstrated the important role of myocytes in the process of tissue remodeling, confirming that VEGF $_{165}$ seems to provide a protective effect in the treatment of acute myocardial infarct.
\end{abstract}

Keywords: Myocardial infarction; Genetic therapy; Angiogenesis inducing agents; Neovascularization physiologic; Vascular endothelial growth factors

\section{RESUMO}

Objetivo: Avaliar os efeitos da transferência gênica do $\operatorname{VEGF}_{165}$ no processo de remodelamento da matriz extracelular após infarto agudo do miocárdio. Métodos: Ratos Wistar foram submetidos ao infarto do miocárdio por ligação da artéria coronária descendente esquerda, e a fração de ejeção de ventrículo esquerdo foi utilizada para classificar os infartos em grandes e pequenos. Os animais foram divididos em grupos de dez animais, de acordo com o tamanho do infarto (grande ou pequeno), e receberam ou não tratamento com o $\mathrm{VEGF}_{165}$. $\mathrm{A}$ avaliação dos diferentes marcadores foi realizada por imuno-histoquímica e quantificação digital. Os anticorpos primários utilizados foram antifibronectina, antivimentina, anti- CD44, anti-E-caderina, anti-CD24, anti-alfa-1-actina e anti-PCNA. 0s resultados foram representados como média e erro padrão, e analisados por ANOVA, sendo considerado estatisticamente significativo se $p \leq 0,05$. Resultados: Houve aumento significativo da expressão de marcadores de células indiferenciadas, como fibronectina (proteína presente na matriz extracelular) e CD44 (glicoproteína presente nas células endoteliais). Entretanto, houve diminuição da expressão de vimentina e PCNA, indicando possível diminuição do processo de proliferação celular após 0 tratamento com $\mathrm{VEGF}_{165}$. Os marcadores de células diferenciadas, E-caderina (proteína de adesão entre as células do miocárdio), CD24 (proteína presente nos vasos sanguíneos) e alfa-1-actina (marcador especifico de miócitos) também apresentaram maior expressão nos grupos submetidos à terapia gênica, comparativamente com o grupo não tratado. 0 valor obtido pela relação entre alfa-1-actina e vimentina foi aproximadamente três vezes maior nos grupos tratados com VEGF $_{165^{\prime}}$ indicando maior diferenciação tecidual. Conclusão: 0 papel dos miócitos se mostrou importante no processo de remodelamento tecidual, confirmando que o $\mathrm{VEGF}_{165}$ parece conferir um efeito protetor no tratamento do infarto agudo do miocárdio.

Descritores: Infarto do miocárdio; Terapia genética; Indutores da angiogênese; Neovascularização fisiológica; Fatores de crescimento do endotélio vascular

\footnotetext{
' Faculdade de Medicina do ABC, Santo André, SP, Brazil.

${ }^{2}$ Universidade Federal de São Paulo, São Paulo, SP, Brazil.

Corresponding author: Larissa Ferraz Garcia - Avenida Príncipe de Gales, 821 - Príncipe de Gales - Santo André, SP, Brazil -Zip code: 09060-650 - Phone: (55 11) 4993-5400 - E-mail: comunicacao@fmabc.br Received on: Sep 16, 2013 - Accepted on: Jan 10, 2015

Conflict of interest: none.

DOI: 10.1590/S1679-45082015AO2970
} 


\section{INTRODUCTION}

Cardiovascular disease represents one of the main causes of mortality in the world. (1) Unfortunately, current pharmacological treatment for acute myocardial infarction is limited as to the process of ventricle remodeling, besides not preventing progression to cardiac failure. ${ }^{(2-4)}$

Gene therapy represents an alternative modality of treatment for cardiac diseases, since it intensifies the action of exogenous angiogenic factors, therefore inducing the formation of new arterial capillaries and promoting remodeling of existing vessels. ${ }^{(5)}$ The possible benefits of gene therapy within the context of acute myocardial infarct include, besides intensification of the action of angiogenic factors, the promotion of myocyte protection (by inhibiting cellular processes such as apoptosis and guaranteeing cell survival) and the alteration of the expression of components responsible for the integrity of the ventricular extracellular matrix. ${ }^{(6-9)}$ The vascular endothelial growth factor (VEGF) protein shows molecular heterogeneity and has five different isoforms with 121, 145, 165, 189, and 206 amino acids. Its most common form is a polypeptide homodimer with 165 or 121 amino acids $\left(\mathrm{VEGF}_{165}\right.$ and $\mathrm{VEGF}_{121}$ ), and both are capable of increasing the collateral blood flow in experimental models. VEGF ${ }_{121}$ regulates vascular permeability, while $\mathrm{VEGF}_{165}$ regulates angiogenesis. ${ }^{(10)}$

VEGF $_{165}$ is a potent mitogen of endothelial cells of arteries, veins, and lymphatic vessels, since besides stimulating the proliferation and migration of endothelial cells, it promotes the formation of new vessels and increases vascular permeability. ${ }^{(10-12)}$ The expansion of collateral vessels in the infarcted myocardial tissue, triggers invasion and proliferation of endothelial cells and smooth muscle cells, inducing responses such as mitosis, migration, cell differentiation, degradation, and remodeling of the extracellular matrix. In the heart of an adult individual, the genes that encode induction factors for formation of new vessels, as well as their receptors, are expressed at levels apparently insufficient in response to a chronic ischemia. ${ }^{(13,14)}$

VEGF $_{165}$ presents hypoxia-induced expression and promotes the differentiation of mesenchymal stem-cells in various types of specialized cells, including myocytes, therefore allowing greater cardiac protection, followed by formation of new vessels in the ischemic myocardium. ${ }^{(15)}$

The overexpression of $\mathrm{VEGF}_{165}$ during survival of the myocytes under conditions of hypoxia, besides stimulating the formation of new blood vessels, increases the vascular density and the blood flow in the infarcted zone. Neovascularization determined by $\mathrm{VEGF}_{165}$ is responsible for the decrease in apoptosis of myocytes and for the increased contractility of the cardiac ventricles. ${ }^{(15,16)}$ In this way, gene therapy with $\mathrm{VEGF}_{165}$ can affect the fibrous remodeling in the ischemic area and impede the expansion of the scar. ${ }^{(17)}$

Recent studies have suggested a broader role for VEGF $_{165}$ in the maintenance of the ventricular function, since the drop in number of myocytes associated with myocardial infarct leads to a relative state of deficiency of VEGF $_{165}$ and this fact contributes towards an alteration of normal cardiac function and of the ventricular structure. Consequently, such discoveries make evident an autocrine and paracrine role of $\mathrm{VEGF}_{165}$ that seems to be able to confer a protective effect on myocardium and extracellular heart matrix, which extends to its role in the formation of new vessels. ${ }^{(18,19)}$

Alterations of molecules of the extracellular matrix and of the surface of myocytes after an acute myocardial infarction were evaluated by the antibodies that identify cell differentiation and tissue proliferation, such as an adhesive glycoprotein present in the soluble form in the plasma and insoluble in the extracellular matrix of most tissues responsible for the interaction between the cell surface and the component of the extracellular matrix (anti-fibronectin), cell surface receptor present in monocytes and vascular endothelium cells (anti-CD44), intermediate filament of fibroblasts and mesenchymal cells (anti-vimentin), adhesion protein present in cardiac cells that guarantee adhesion during systole and diastole (anti-E-cadherin), blood vessel marker (anti-CD24), myocyte-specific market (anti-alpha-1actin), and the marker that identifies the process of cell proliferation, defined as proliferating cell nuclear antigen - anti-PCNA. ${ }^{(19)}$

\section{OBJECTIVE}

Evaluate the effects of $\mathrm{VEGF}_{165}$ gene transfer in the process of remodeling of the extracellular matrix after an acute myocardial infarct.

\section{METHODS}

\section{Animal Model}

Wistar rates (adult females) were anesthetized and submitted to ligation of the left descending coronary artery to provoke an infarction, with subsequent gene transfer to the treated animal group, as previously described by Mataveli et al. ${ }^{(13)} \mathrm{Next}, 250 \mu \mathrm{g}$ of recombinant DNA plasmid (cDNA) of $\mathrm{VEGF}_{165}\left(\mathrm{pVEGF}_{16} 5\right)$ were 
injected in $150 \mu \mathrm{l}$ of $0.1 \mathrm{M}$ phosphate buffer immediately after the induced infarct. The intramyocardial injection was done at three equidistant points, around the area irrigated by the left portion of the descending coronary artery.

Six weeks after induction of acute myocardial infarction, all animals were submitted to echocardiography before being euthanized. The test had the objective of calculating the size of the infarction on the anterior wall of the left ventricle (LV) and measuring the ejection fraction (EF) as a dimension of cardiac function, as described in detail by Mataveli et al. ${ }^{(13)}$

The groups of animals were divided according to the size of the infarction, that is, infarctions that reached less than $30 \%$ of the anterior LV wall were considered small (SAMI), and infarcts that reached more than $30 \%$ of the anterior wall of the LV were considered large (LAMI). The group of animals that suffered infarction (LAMI or SAMI) received no treatment with $\mathrm{pVEGF}_{165}$, but served as controls. Each group was made up of ten animals.

This project was approved by the Ethics in Animal Research Committee of the Universidade Federal de São Paulo (UNIFESP), process number 0933/07. Infarct induction in animals was conducted at the animal house of the National Institute of Pharmacology of UNIFESP, during the period between 2008 and 2010. Nevertheless, the immunohistochemical analyses of the different markers were done at the Biochemistry Department Laboratory, at the Faculdade de Medicina do $A B C$, during the period between 2009 and 2012.

\section{Immunohistochemistry reactions}

The primary antibodies used were: anti-fibronectin (sc-6953, Santa Cruz Biotechnology, California, United States), anti-CD-44 (AM310-5M, BioGenex ${ }^{\circledR}$, Andhra Pradesh, India), anti-vimentin (sc-7558, Santa Cruz Biotechnology, California, United States), anti-E-cadherin (number 4,065, Cell Signaling Technology Inc ${ }^{\circledR}$, Beverly Hills, United States), anti-CD-24 (sc-7036, Santa Cruz Biotechnology, California, United States), anti-alpha-1-actin (M0851, Dako $^{\circledR}$, Glostrup, Denmark), and anti-PCNA (sc-56, Santa Cruz Biotechnology, California, United States). The secondary antibody used was LSAB-HRP (Large Streptavidin-Avidin-Biotin-; System Peroxidase; k-0690; Dako $^{\circledR}$, Glostrup, Denmark). The slides were developed with a chromogene (3-3'-diaminobenzidine (DAB), obtained from Sigma Diagnostics ${ }^{\circledR}$, St. Louis, United States, and counterstained with Harris's hematoxylin (Sigma Diagnostics ${ }^{\circledR}$, St. Louis, United States).

\section{Digital quantification of the immunohistochemistry reactions}

For the quantitative analysis of the immunohistochemistry reactions, digital image processing software was used (ImageLab ${ }^{\circledR}$, Rio de Janeiro, Brazil), following the instructions described by Matos et al. ${ }^{(20)}$ Digital quantification of each immunohistochemical reaction was determined as an expression index (EI), indicated in optic units $/ \mathrm{mm}^{2}\left(\mathrm{ou} / \mathrm{mm}^{2}\right)$.

\section{Statistical analyses}

The results were expressed as means and standard deviation or median and interquartile variation, assessed by Analysis of Variance (ANOVA), and was considered statistically significant if $p \leq 0.05$. For the statistical analyses, the Statistical Package for Social Science (SPSS) software was used, version 13.0 (SPSS Inc., Illinois, United States).

\section{RESULTS}

The results were presented according to the group of markers that determined cell undifferentiation, differentiation, and proliferation.

\section{Evaluation of the cell undifferentiation markers}

The gene transfer of $\mathrm{VEGF}_{165}$ increased the expression of specific markers that identified undifferentiated cells, such as fibronectin, CD44, and vimentin, as is shown in figure 1 .

An increase in the expression of fibronectin and of CD44 was noted in the infarcted tissues treated with VEGF $_{165}$ comparatively with the respective tissues of infarcted groups and not treated with $\mathrm{VEGF}_{165^{\circ}}$ However, vimentin, showed a decrease in expression in the infarcted groups, after treatment with gene therapy, as can be observed in figure 1 .

Figure 1 also shows that there was a significant increase in the expression of fibronectin for the group of animals with SAMI, treated with $\mathrm{VEGF}_{165}$, comparatively with the non-treated group - respectively $21.74 \pm 6.00 \mathrm{ou} / \mu \mathrm{m}^{2}$ and $4.62 \pm 1.43 \mathrm{ou} / \mu \mathrm{m}^{2}$, with $\mathrm{p}=0.0125$. Nevertheless, there was no statistically significant difference in the expression of fibronectin when comparing the group of animals who suffered a treated or nontreated LAMI: $18.2 \pm 4.72 \mathrm{ou} / \mu \mathrm{m}^{2}$ and $11.45 \pm 2.61 \mathrm{ou} / \mu \mathrm{m}^{2}$, respectively, with $\mathrm{p}=0.2108$.

The significant increase of CD44 for the groups of animals treated with gene transfer, containing the $\mathrm{VEGF}_{165}$ factor, is also demonstrated in figure 1 . 

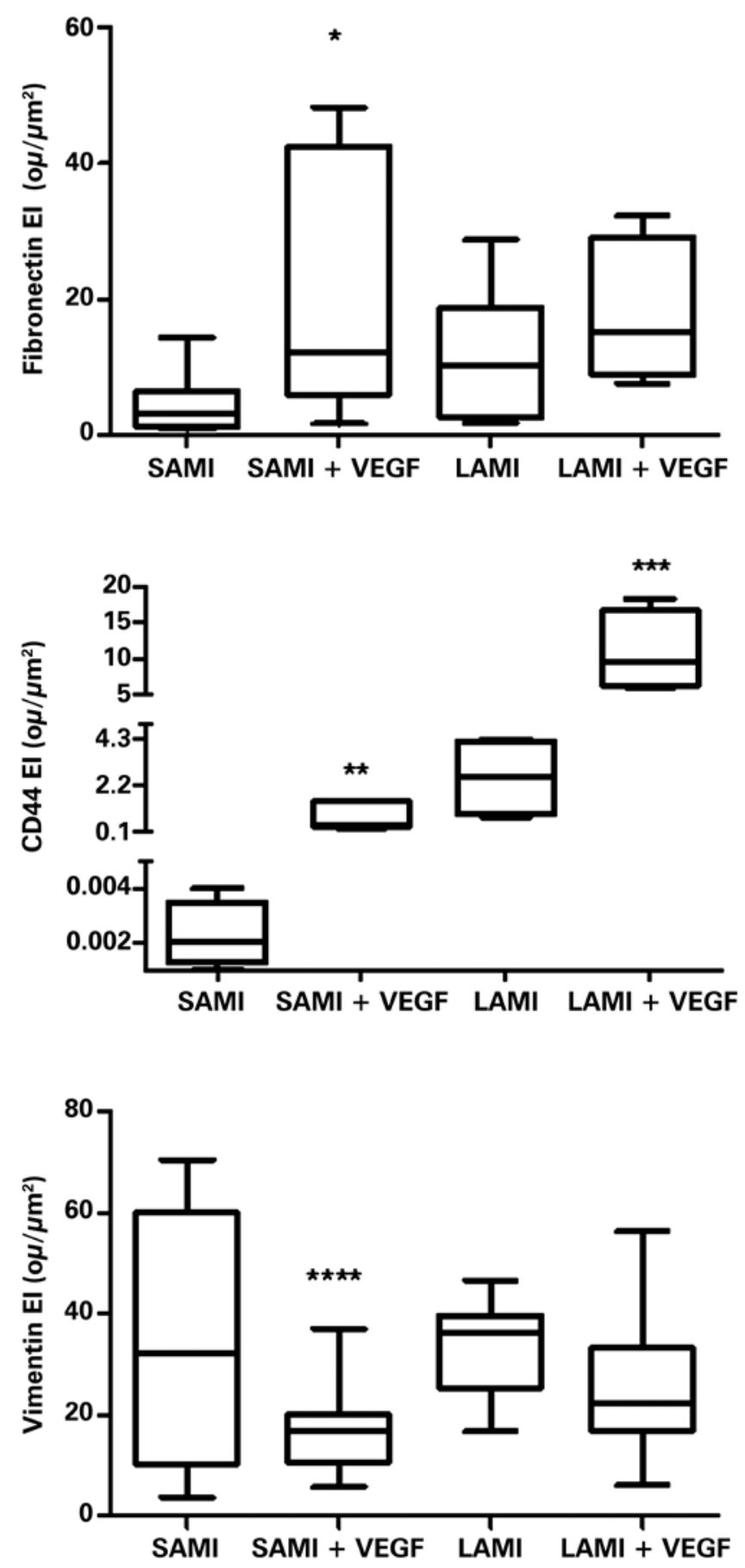

Figure 1. Expression of fibronectin, $C D 44$, and vimentin in infarcted animals, submitted or not to treatment with VEGF ${ }_{165}$. The values indicate the median and the interquartile variation, obtained by statistical analysis after determining the expression index (EI), by digital quantification of the immunohistochemical reactions, as was described in details in Methods. There were ten $(n=10)$ animals in each group. Asterisks indicate the $p$-values obtained for each marker, comparing the results obtidos from animals treated with VEGF versus the non-treated group. ${ }^{*} \mathrm{p}=0.0125 ;{ }^{* *} \mathrm{p}=0.0358 ;{ }^{* *} \mathrm{p}=0.0299$; $* * * p=0.0120$. SAMI: group of animals submitted to acute myocardial infarction (small infarction) without treatment; SAMI + VEGF: group of animals submitted to acute myocardial infarction (small infarction) treated with gene transfer containing VEGF ${ }_{165}$; LAMI: group of animals submitted to acute myocardial infarction (large infarction) without treatment; LAMI + VEGF: group of animals submitted to acute myocardial infarction (large infarction) treated with gene transfer containing $\mathrm{VEGF}_{165}$.
Values obtained for the non-treated and treated SAMI groups were, respectively, $0.0023 \pm 0.01 \mathrm{ou} / \mu \mathrm{m}^{2}$ and $0.82 \pm 0.27 \mathrm{ou} / \mu \mathrm{m}^{2}$, with $\left.\mathrm{p}=0.0358\right)$. In the LAMI group, the values obtained for CD44 expression were $2.57 \pm 0.91 \mathrm{ou} / \mu \mathrm{m}^{2}$ for the group without treatment and $10.83 \pm 2.76 \mathrm{ou} / \mu \mathrm{m}^{2}$ for the treated with $\mathrm{VEGF}_{165}$ $(p=0.0299)$, as is shown in figure 1 .

There was greater expression of vimentin in the groups of animals not treated with $\mathrm{VEGF}_{165}$, as can be observed in figure 1, both for LAMI and for SAMI. One can clearly see the significant decrease in the expression of vimentin, when comparing, respectively, the SAMI groups non-treated and treated with $\mathrm{VEGF}_{165}: 34.18 \pm 6.81 \mathrm{ou} / \mu \mathrm{m}^{2}$ and $17.11 \pm 2.02 \mathrm{ou} / \mu \mathrm{m}^{2}$, with $\mathrm{p}=0.0120$. However, there was no statistical difference for the non-treated LAMI group $\left(34.00 \pm 3.45 \mathrm{ou} / \mu \mathrm{m}^{2}\right)$ and that treated with $\mathrm{VEGF}_{165}\left(25.58 \pm 3.025 \mathrm{ou} / \mu \mathrm{m}^{2}\right)$, with $\mathrm{p}=0.1122$.

\section{Evaluation of the cell differentiation markers}

The markers of cellular differentiation were increased in the infarcted tissues that received the recombinant plasmid containing $\mathrm{VEGF}_{165}$, compared to the tissues from the non-treated group.

The E-cadherin showed a significant increase in expression in the LAMI group that received gene therapy, in comparison with the non-treated group (respectively, $34.08 \pm 5.03 \mathrm{ou} / \mu \mathrm{m}^{2}$ and $12.40 \pm 6.37 \mathrm{ou} / \mu \mathrm{m}^{2}$; $\mathrm{p}=0.0331$ ), as shown in figure 2 . However, no significant difference was seen between the treated group of SAMI and the non-treated with $\mathrm{VEGF}_{165}$ (respectively, $26.87 \pm 5.52 \mathrm{ou} / \mu \mathrm{m}^{2}$ and $\left.25.35 \pm 4.93 \mathrm{ou} / \mu \mathrm{m}^{2} ; \mathrm{p}=0.8419\right)$, as can be seen in figure 2 .

Marking of differentiated cells with specific antibodies targeted at proteins present in blood vessels (CD24) and in myocytes (alpha-1-actin) was also analyzed.

The number of vessels, identified by antibody anti-CD24, showed a significant increase $(p=0.0018)$ in the tissues collected from the SAMI group that received treatment with $\mathrm{VEGF}_{165}$ relative to the nontreated animals (respectively, $10.04 \pm 1.69 \mathrm{ou} / \mu \mathrm{m}^{2}$ and $\left.0.46 \pm 0.44 \mathrm{ou} / \mu \mathrm{m}^{2}\right)$, as can be seen in figure 2 .

No significant difference was observed in the expression of CD24 ( $p=0.1626)$, when compared to the LAMI group, submitted or not to transfer with $\mathrm{VEGF}_{165}$ (respectively, $5.56 \pm 0.91 \mathrm{ou} / \mu \mathrm{m}^{2}$ and $7.45 \pm 0.86 \mathrm{ou} / \mu \mathrm{m}^{2}$ ).

The anti-alpha-1-actin antibody also showed an expressive increase $(p=0.0490)$ in the tissues of animals that presented with SAMI treated with $\mathrm{VEGF}_{165}$ $\left(16.26 \pm 1.99 \mathrm{ou} / \mu \mathrm{m}^{2}\right)$ compared with tissues of non-treated animals $\left(10.20 \pm 1.69 \mathrm{ou} / \mu \mathrm{m}^{2}\right)$, as can be seen in figure 2 . 

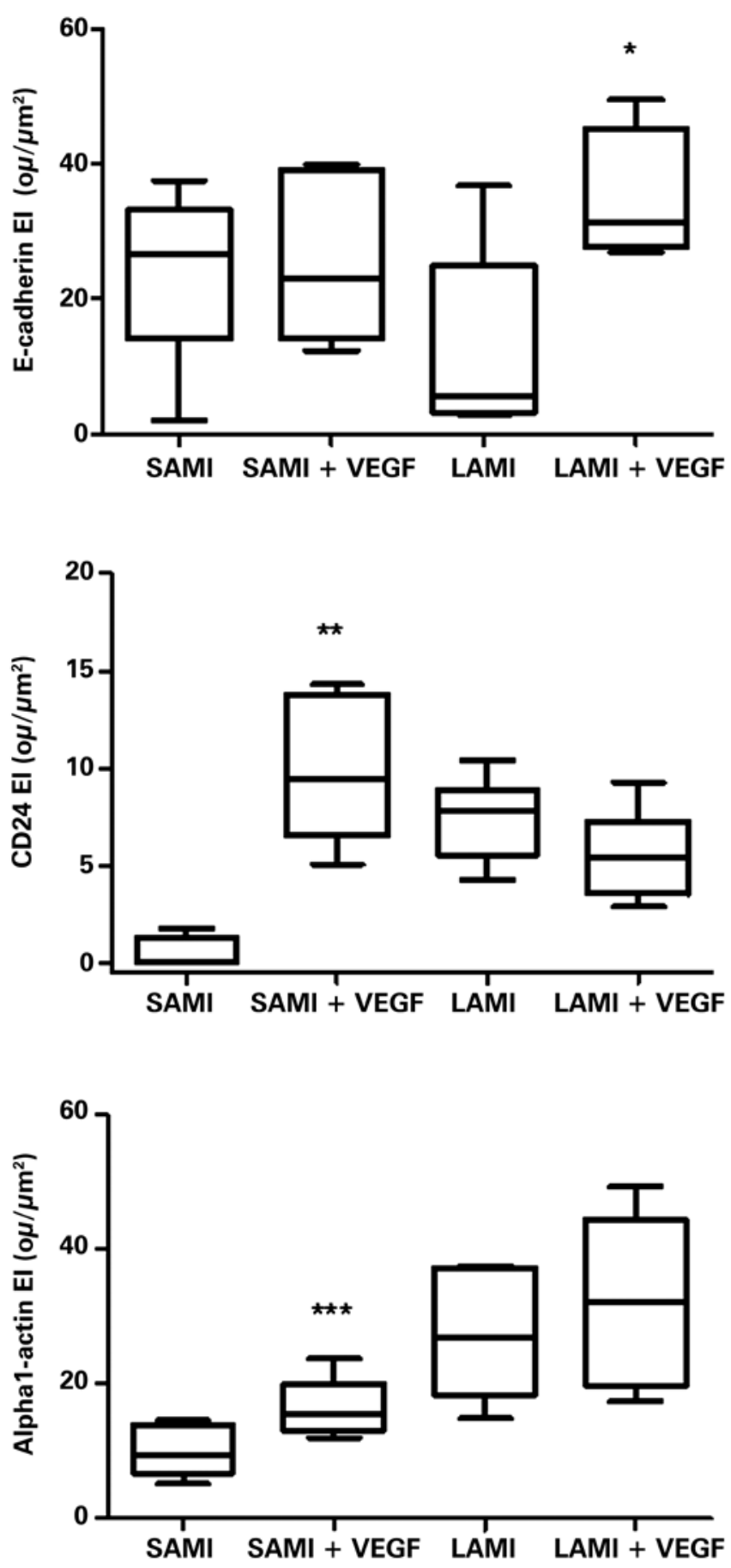

Figure 2. Expression of E-cadherin, CD24, and alpha-1-actin in infarcted animals submitted or not to treatment with VEGF ${ }_{165}$. The values indicate the median and interquartile range, obtained by statistical analysis after obtaining the expression index (EI), by digital quantification of the immunohistochemistry reactions, as described in detail in Methods. The number of animals in each group was ten $(n=10)$. Asterisks $\left({ }^{*}\right)$ indicate the $p$-values obtained for each marker, comparing the results acquired of animals treated with VEGF versus the non-treated group. ${ }^{*} p=0.0331 ;{ }^{* *} p=0.0018 ;{ }^{* *} p=0.0490$. SAMI: group of animals submitted to acute myocardial infarction (small infarction) without treatment; SAMI + VEGF: group of animals submitted to acute myocardial infarction (small infarction) treated with gene transfer containing VEGF ${ }_{165}{ }^{\circ}$ LAMI: group of animals submitted to acute myocardial infarction (large infarction) without treatment; LAMI + VEGF: group of animals submitted to acute myocardial infarction (large infarction) treated with gene transfer containing VEGF ${ }_{165}$.
There was no significant difference $(\mathrm{p}=0.5534)$ in the expression of alpha-1-actin among the groups of animals affected with LAMI, treated with VEGF $_{165}$ $\left(27.54 \pm 4.38 \mathrm{ou} / \mu \mathrm{m}^{2}\right)$ and non-treated $\left(32.02 \pm 5.70 \mathrm{ou} / \mu \mathrm{m}^{2}\right)$, as is shown in figure 2 .

\section{Relation between differentiation and undifferentiation markerstion}

The mean values of EI, obtained by digital quantification of the immunohistochemical reactions, utilizing the different antibodies that mark undifferentiated cells (fibronectin, vimentin, and CD44) and differentiated cells (E-cadherin, CD24, and alpha-1-actin), are summarized on table 1.

Table 1. Expression index of markers of differentiated and undifferentiated cells

\begin{tabular}{lcccccc}
\hline & Fibronectin & Vimentin & CD44 & E-cadherin & CD24 & $\begin{array}{c}\text { Alpha-1- } \\
\text { actin }\end{array}$ \\
\hline SAMI & 4.62 & 34.18 & 0 & 26.87 & 0.46 & 10.20 \\
SAMI + VEGF & 21.74 & 17.10 & 0.82 & 25.35 & 10.04 & 16.26 \\
LAMI & 11.45 & 34.00 & 2.57 & 12.40 & 7.45 & 27.54 \\
LAMI + VEGF & 18.12 & 25.58 & 10.83 & 34.80 & 5.56 & 32.02 \\
\hline SAMI: small infarciont; LAMl: large infarction; VEGF: animals treated with injection of the recombinant plasmid containing $^{\text {VEGF }_{165}}$ &
\end{tabular}

Table 2 shows the value that expresses the relation between the EI of alpha-1-actin (differentiation marker) and vimentin (undifferentiation marker). The greatest value obtained by the alpha-1-actin/vimentin relation indicated that there was a greater degree of cellular differentiation of the tissue analyzed. The choice of alpha-1-actin and vimentin as markers of cell differentiation and undifferentiation was due to the fact that both markers are present in the interior of differentiated (myocytes) and undifferentiated cells, as was mentioned before.

Table 2. Alpha-1-actin and vimentin relation. Note the evidence of the myocardial differentiation level

\begin{tabular}{lc}
\hline Groups & Alpha-1-actin/vimentin \\
\hline SAMI & 0.3 \\
SAMI + VEGF & 0.95 \\
LAMI & 0.81 \\
LAMI + VEGF & 1.03 \\
\hline SAMI: small infarction; LAMI: large infarction; VEGF: animals treated with injection of recombinant plasmid containing \\
VEGF $_{165}$
\end{tabular}

Tissues of animals from the group submitted to treatment with $\mathrm{VEGF}_{165}$ presented with approximately 
three times greater proportion of cell differentiation markers, comparatively with their respective nontreated groups. This relation shows the increase in proportion of myocytes, after treatment with $\mathrm{VEGF}_{165}$, which suggests that such differentiated cells are important in tissue remodeling.

\section{Evaluation of cell proliferation}

PCNA was significantly diminished in the animals submitted to treatment with $\mathrm{VEGF}_{165}$. Relative to the group that suffered a small infarction, the result was, respectively, for those treated with $\mathrm{VEGF}_{165}$ and not treated: $1.92 \pm 0.66 \mathrm{ou} / \mu \mathrm{m}^{2}$ and $14.75 \pm 3.36 \mathrm{ou} / \mu \mathrm{m}^{2}$, with $\mathrm{p}=0.0078$. The group that suffered LAMI presented with the result $22.82 \pm 3.23 \mathrm{ou} / \mu \mathrm{m}^{2}$ for the treated group and $55.70 \pm 6.54 \mathrm{ou} / \mu \mathrm{m}^{2}$ for the non-treated $(\mathrm{p}=0.0006)$, as can be seen in figure 3 .

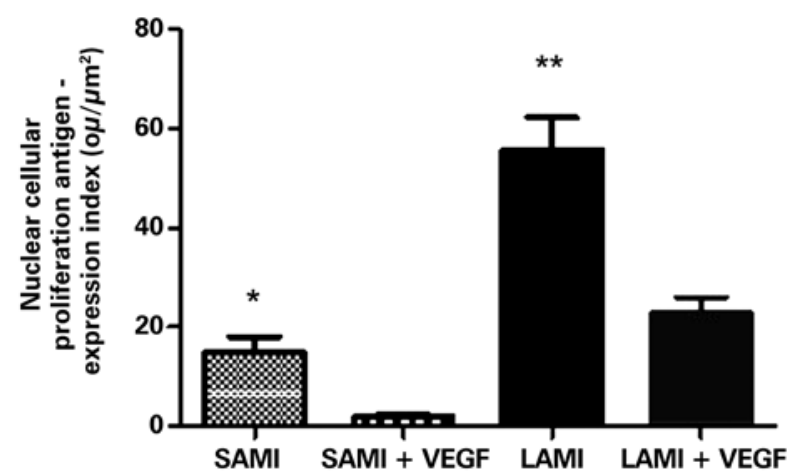

Figure 3. Expression of the nuclear cellular proliferation antigen in infarcted animals submitted or not to treatment with $\mathrm{VEGF}_{165^{\circ}}$. The values indicate the mean and standard deviation by analysis of the expression index, after digital quantification of the immunohistochemical reactions, as is described in methods. The number of animals in each group was $10(n=10)$. Asterisks $\left({ }^{*}\right)$ indicated the $p$ values obtained for each marker, comparing the results acquired of animals treated with VEGF versus the non-treated group. ${ }^{*} p=0.0078$; ${ }^{* *} p=0.0006$. SAMI: group of animals submitted to acute myocardial infarction (small infarction) without treatment; SAMI + VEGF: group of animals submitted to acute myocardial infarction (small infarction) treated with gene transfer containing $\mathrm{VEGF}_{165}$; LAMI: group of animals submitted to acute myocardial infarction (large infarction) without treatment; LAMI + VEGF: group of animals submitted to acute myocardial infarction (large infarction) treated with gene transfer containing $\mathrm{VEGF}_{165}$.

\section{DISCUSSION}

In results previously published by our group, it was described that the maximal expression of $\mathrm{VEGF}_{165}$ occurs 14 days after gene transfer. Consequently, the evaluation of the samples was done within the period of 6 weeks after induction of the infarction and posterior treatment with gene transfer. Therefore, the late response of the effect promoted by treatment with $\mathrm{VEGF}_{165}$ was evaluated, as had been previously described by Mataveli et al. ${ }^{(13)}$
Literature data suggest that the increase in expression of molecules that determine undifferentiation might be related to the increased degree in cell proliferation. ${ }^{(10)}$ Results obtained from the present study suggest that the increased expression of fibronectin in the infarcted area is related to greater cell proliferation, which occurs in the myocardium after treatment with $\mathrm{VEGF}_{165}$ (specifically in the areas of small infarction).

The significant increase of CD44 after treatment with $\mathrm{VEGF}_{165}$ indicated the formation and regeneration of blood vessels in the myocardium after the infarct, regardless of the size of the infarct.

The decrease in expression of vimentin, which corresponds to an intermediate filament of the cytoskeleton, characteristic of fibroblasts and mesenchymal cells, demonstrated that possibly such cells were not responsible for the processes of cardiac tissue remodeling after the myocardial infarction.

It is important to point out that E-cadherin represents an adhesion protein present in cardiac cells and serves to maintain systole and diastole. ${ }^{(16,19)}$ The increased expression of E-cadherin after treatment with VEGF $_{165}$ indicates that it is likely that this marker has a fundamental role in the protection and maintenance of cardiac contractility, stimulated by gene transfer with $\mathrm{VEGF}_{165}$, mainly in areas of a large infarction.

The increased expression of CD24 in the SAMI group treated with gene transfer suggested that $\mathrm{VEGF}_{165}$ could stimulate the proliferation and migration of endothelial cells, hence promoting the formation of new vessels and greater ease in myocardial tissue regeneration.

An increase in number of blood vessels would be expected after treatment with $\mathrm{VEGF}_{165}$ in both groups of animals, with a small or large infarcted area. However, no significant increase was observed in CD24 in the areas of large infarction. Possibly, the $\mathrm{VEGF}_{165}$ demonstrated a more effective role in treating small myocardial lesions.

The increased expression of the antibody antialpha-1-actin in the groups submitted to gene therapy indicated that such a growth factor likely promoted the induction of myocyte proliferation. Therefore, the data obtained demonstrated that myocytes were possibly involved in the process of myocardial extracellular matrix remodeling after the infarction.

The fact that no difference was observed in marking of the myocytes in the tissues of animals of the large infarct group made evident, once again, that possibly VEGF $_{165}$ was not effective in inducing the proliferation of myocytes, when the area affected by the infarction was very large. 
The groups that received treatment with $\mathrm{VEGF}_{165}$ presented with lower expression of PCNA and, therefore, less cell proliferation. The decrease in rate of tissue proliferation after gene transfer of $\mathrm{VEGF}_{165}$ corroborates the data already mentioned that evidenced an intense process of cell differentiation.

Therefore, six weeks after the treatment with $\mathrm{VEGF}_{165}$, it was possible to demonstrate that $\mathrm{VEGF}_{165}$ was related to alterations in the infarction area, responsible for the increased expression of markers specific for cell differentiation. Additionally, the results demonstrated that myocytes were the differentiated cells responsible for such a process. Data obtained in the present study clarified that the damaged tissue after infarction was under intense remodeling and did not present with only scar tissue, as suggested in literature.

\section{CONCLUSIONS}

Treatment with VEGF $_{165}$ represented a fundamental alternative for extracellular matrix remodeling after acute myocardial infarction, promoting stimulation of cell differentiation. Myocytes actively participated in the remodeling process of the extracellular matrix after an acute myocardial infarction.

\section{ACKNOWLEDGMENTS}

We wish to thank the financing obtained for conducting this study from the Fundação de Amparo à Pesquisa do Estado de São Paulo (FAPESP) [State of São Paulo Research Foundation] with Regular Research Grant, Process number 2011/188638-300, of the Conselho Nacional de Desenvolvimento Científico e Tecnológico (CNPq) [National Council of Scientific and Technological Development], Process number 127212/2010-8, and of Coordenação de Aperfeiçoamento de Pessoal de Nivel Superior (CAPES) [Coordination for the Improvement of Higher Education Personnel].

\section{REFERENCES}

1. Sanderson JE, Mayosi B, Yusuf S, Reddy S, Hu S, Chen Z, et al. Global burden of cardiovascular disease. Heart. 2007;93(10):1175

2. McGinn AN, Nam HY, Ou M, Hu N, Straub CM, Yockman JW, et al. Bioreducible polymer-transfected skeletal myoblasts for VEGF delivery to acutely ischemic myocardium. Biomaterials. 2011;32(3):942-9.
3. Katare RG, Kakinuma Y, Arikawa M, Yamasaki F, Sato T. Chronic intermittent fasting improves the survival following large myocardial ischemia by activation of BDNF/NEGF/PI3K signaling pathway. J Mol Cell Cardiol. 2009;46(3):405-12.

4. Novotny NM, Ray R, Markel TA, Crisostomo PR, Wang M, Wang Y, et al. Stem cell therapy in myocardial repair and remodeling. J Am Coll Surg. 2008; 207(3):423-34. Review.

5. Furlani AP, Kalil RA, Castro I, Cañedo-Delgado A, Barra M, Prates PR, et al. Effects of therapeutic angiogenesis with plasmid VEGF165 on ventricular function in a canine model of chronic myocardial infarction. Rev Bras Cir Cardiovasc. 2009;24(2):143-9.

6. Wang R, Crystal RG, Hackett NR. Identification of an exonic splicing silencer in exon 6A of the human VEGF gene. BMC Mol Biol. 2009;10:103.

7. Ward MR, Stewart DJ. Progenitor cell therapy for cardiac regeneration following acute myocardial infarction: So far, so good? Can J Cardiol. 2008;24(Suppl C): 5C-10C.

8. Payne TR, Oshima H, Okada M, Momoi N, Tobita K, Keller BB, et al. A relationship between vascular endothelial growth factor, angiogenesis, and cardiac repair after muscle stem cell transplantation into ischemic hearts. J Am Coll Cardiol. 2007:50(17):1677-84.

9. Kivelä R, Bry M, Robciuc MR, Räsänen $M$, Taavitsainen $M$, Silvola JM, et al. VEGF-B-induced vascular growth leads to metabolic reprogramming and ischemia resistance in the heart. EMBO Mol Med. 2014 Mar;6(3):307-21.

10. Levashova Z, Backer M, Backer JM, Blankenberg FG. Imaging vascular endothelial growth factor (VEGF) receptors in turpentine-induced sterile thigh abscesses with radiolabeled single-chain VEGF. J Nucl Med. 2009;50(12):2058-63.

11. Yan D, Wang X, Li D, Liu W, Li M, Qu Z, et al. Macrophages overexpressing VEGF target to infarcted myocardium and improve neovascularization and cardiac function. Int J Cardiol. 2013;164(3):334-8.

12. Sato D, Otani H, Enoki C, Fujjta M, Minato N, Iwasaka T. Phenotypic modulation and turnover of bone marrow-derived cells after myocardial infarction in rats. Cardiovasc Pathol. 2011;20(3):146-55.

13. Mataveli FD, Han SW, Nader HB, Mendes A, Kanishiro R, Tucci P, et al. Long-term effects for acute phase myocardial infarct VEGF165 gene transfer cardiac extracellular matrix remodeling. Growth Factors. 2009;27(1):22-31.

14. Jujo K, Li M, Losordo DW. Endothelial progenitor cells in neovascularization of infarcted myocardium. J Mol Cell Cardiol. 2008;45(4):530-44. Review.

15. Ye L, Zhang W, Su LP, Haider HK, Poh KK, Galupo MJ, et al. Nanoparticle based delivery of hypoxia-regulated VEGF transgene system combined with myoblast engraftment for myocardial repair. Biomaterials. 2011;32(9):2424-31.

16. Zhang Y, Furumura M, Morita E. Distinct signaling pathways confer different vascular responses to VEGF 121 and VEGF 165. Growth Factors. 2008;26(3):125-31.

17. Hagikura K, Fukuda N, Yokoyama S, Yuxin L, Kusumi Y, Matsumoto T, et al. Low invasive angiogenic therapy for myocardial infarction by retrograde transplantation of mononuclear cells expressing the VEGF gene. Int J Cardiol. 2010;142(1):56-64.

18. Vilahur G, Juan-Babot O, Peña E, Oñate B, Casaní L, Badimon L. Molecular and cellular mechanisms involved in cardiac remodeling after acute myocardial infarction. J Mol Cell Cardiol. 2011;50(3):522-33.

19. Xu H, Shi BM, Lu XF, Liang F, Jin X, Wu TH, et al. Vascular endothelial growth factor attenuates hepatic sinusoidal capillarization in thioacetamide-induced cirrhotic rats. World J Gastroenterol. 2008;14(15):2349-57.

20. Matos LL, Stabenow E, Tavares MR, Ferraz AR, Capelozzi VL, Pinhal MA Immunohistochemistry quantification by a digital computer-assisted method compared to semiquantitative analysis. Clinics (São Paulo). 2006;61 (5):417-24. 